\title{
ANNOTATION
}

\section{Research in the Prevention of Blindness}

On April 20, 1938, the headquarters of the W. H. Ross Foundation for the Study of Prevention of Blindness was opened at 20, Lauriston Place, Edinburgh. The Foundation owes its initiation to the generosity of Mr. William H. Ross, who gave $£ 40,000$ for this purpose. Mr. Ross, in a speech which was read by Dr. Traquair, alluded to his own deterioration of sight, which, beginning in the year 1929, ended in total blindness in 1933 .

Mr. Ross felt that he would like to be the means of saving his fellows from ever sharing the same fate, and eventually settled that the best way was to inaugurate a fund for the investigation into the causes of blindness, to be aided by research and study of the best means to prevent blindness. The Trustees of the Foundation are Dr. A. H. H. Sinclair, Mr. W. H. Fraser, W.S., and Mr. H. J. Ross, a son of the founder. Colonel R. M. Dickson, C.B.E., A.M.S., has been appointed Director, and the Honorary Staff of the Eye Department of the Royal Infirmary constitutes the Committee of Management under the Chairmanship of Dr. Sinclair.

The ceremony was performed by Mr. W. S. Douglas, Secretary to the Department of Health for Scotland, who, in a brief speech, alluded to the benefits that are likely to accrue from this Foundation, and promised the close co-operation and assistance of his department.

Dr. Sinclair, in explaining the work which had already been undertaken, said that he would only mention two of the investigations in progress. First, under the heading of industrial injuries, hypopyon ulcer of the cornea in coal miners, which represented 52 per cent. of all cases of corneal ulcer of this type treated at the Royal Infirmary. This investigation included an extensive examination of the bacteriology of the eyes of all classes of miners, some 800 having already been examined. The second line of research related to glaucoma.

The Foundation works in close co-operation with the medical faculty in Edinburgh, including the Royal Infirmary, and has the goodwill of ophthalmologists throughout Scotland. This was especially emphasized by Professor Ballantyne of Glasgow who pointed out that the prevention of blindness was a problem that could not be solved by individual effort but emphatically needed team work.

A description of the ceremony, accompanied by a leading article and an illustration appeared in "The Scotsman" of April 21, 
and we should not omit to record our thanks to "The Scotsman " for most of the details given here. Mr. Ross will have the satisfaction of knowing how keenly his generosity is appreciated, not only in Scotland but throughout the empire and indeed the whole of the civilized world.

British Ophthalmology will wish God speed to the Foundation and the beneficent work which is undertaken.

\section{THE COUNCIL OF BRITISH OPHTHALMOLOGISTS}

\section{Annual Report}

The Council presents its report for the year 1937-38. At its first meeting in July the following were elected officers :-President : Sir John Parsons; Vice-Presidents: Mr. R. A. Greeves, Mr. F. A. Juler ; Hon. Treasurer: Mr. A. H. Levy; Hon. Secretary: Mr. M. L. Hepburn.

The following were appointed to serve on the Executive Committee :-The President, Hon. Secretary and Hon. Treasurer. (ex-officiis), with Messrs. Cardell, Greeves, Juler, Neame and Miss Ida Mann. Messrs. Juler and Neame were elected to represent the Council on the Ophthalmic Committee of the British Medical Association.

The Council has to record with much regret the death of $\mathrm{Mr}$. William Lang who was one of the original members, but has been unable to take any active part in its work for many years.

During the year the Council has completed its investigations into the question of the visual standards required of candidates for L.C.C. Scholarships and Teacherships, and certain modifications of those laid down in 1924 have been made and approved by the Council. These new standards of vision have been accepted by the L.C.C. and are now being acted upon.

The Council continues to supervise the proceedings of the Orthoptic Board, a duty which it assumed two years ago. A register is kept of those qualified by examination to undertake Orthoptic training.

The expenses of the Council have been met out of the funds in the hands of the Hon. Treasurer, of which there is still a credit balance. 